\title{
The Influence of Business Strategy Through the Management Accounting Information System to the Quality of Management Accounting Information - Evidence in Indonesia.
}

\author{
Lilis Puspitawati \\ Departement Accounting, Economic And Business Faculty \\ Universitas Komputer Indonesia \\ Bandung,Indonesia \\ Lilis.puspitawati@email.unikom.ac.id
}

\author{
Azhar Susanto \\ Departement Accounting, Economic And Business Faculty \\ Universitas Padjadjaran \\ Bandung,Indonesia \\ Azhars@gmail.com
}

\begin{abstract}
Managers as stakeholders use accounting for strategic management in implementing their business strategy in achieving competitive advantage. Currently, the implementation of strategic management accounting has used information technology known as management accounting information systems. This study aims to examine the effect of business strategy on the effectiveness of management accounting information systems and the effect on the effectiveness of management accounting information systems on the quality of management accounting information. This study used descriptive and verification methods. Respondents in this study were 162 functional managers SOEs in Indonesia... Statistical tests use structural equation models with Lisrell software. Results of this study are Business Strategy have no significant effect on the effectiveness of Management Accounting Information Systems, and Management Accounting Information Systems have a significant effect on the management of accounting information on SOEs in Indonesia.
\end{abstract}

Keywords-business strategy, effectiveness of management accounting information systems, quality of management accounting information.

\section{INTRODUCTION}

Competitive advantage will be achieved when management at various levels of organizational organizations used accounting information systems to produce accounting information that supports strategic advantage, tactical excellence and operational excellence. Management at the highest level uses accounting information systems to change the company's direction in achieving strategic advantage[1]. The middle management uses accounting information system to determine the right type of strategic planning information. Management at the operational level uses an accounting information system to ensure that the company's operations run efficiently and achieve superior corporate operations.

Management accounting information systems are an important instrument in establishing corporate value to achieve competitive advantage management accounting information that can assist managers in making better decisions or management accounting information that can improve the implementation of business processes within an organization [2-3]. The quality of management accounting information is an important resource and strengthen various individuals within an organization[4]. The quality management accounting information impacts the quality of communication. Increasing the quality of communication will also enhance integration within an organization. The increased integration of an organization will improve the organizers' understanding of the organization in looking at changes around the organization so that organizers will be quick and accurate in response to any changes that arise [5].

The quality of management accounting information will be influenced by the quality of management accounting information systems used by an organization. Quality management accounting information system affects the quality of management accounting information. Similiary with this opinion, ineffective management accounting information systems can reduce the quality of financial transactions processing that impact on the resulting low quality of management accounting information[6-7]. Effectiveness of management accounting information systems is the success of management accounting information systems in achieving the goals set. Meanwhile, effectiveness to show the quality of accounting information systems. Effectiveness of management accounting information system is the satisfaction of users of accounting information in obtaining the desired accounting information[9-10].

The effectiveness of management accounting information systems is the ability of management accounting information systems in providing management accounting information needed by managers in a timely and appropriate time[11]. The effectiveness of management accounting information systems is the availability of relevant management accounting information in the decision-making process [12$13]$. 
Effectiveness of management accounting information systems will be influenced by a variety of factors, today's organizations are generally hardening business strategies with the use of information systems to improve organizational performance[14]. Right business strategy is an important factor in managing accounting information systems within an organization[15]. Similarly, business strategy is one of the factors that affect the development and use of accounting information systems in an organization[16].

That business strategy affects management accounting information systems in terms of generating information that management can use at various levels of the organization to achieve competitive advantage. Achieve competitive advantage required management accounting information system which is a provider of information for organizations that can be used organization to increase sales (market place) higher[17].

In general, business strategy exists in all business units, divisions or product levels that refer to how an organization competes in each type of activity and strives to achieve competitive advantage with its competitors [18]. Business strategy is an important factor to enhance the position of competitive advantage in an organization by using industry specific to appropriate market segmentation[19].

Based on the Introduction described earlier, This study aims to examine the effect of business strategy on the effectiveness of management accounting information systems and the effect of the effectiveness of management accounting information systems on the quality of management accounting information.

\section{LITERATURE REVIEW}

\section{A. Management Accounting System}

Accounting information system is an integration of various physical and nonphysical components that are interrelated in harmony to process financial data into financial information used by users in the decision-making process the accounting information system providing reliable accounting information for decision analysis or as decision makers related to business transactions [20].

Accounting information system is classified into 2 (two) subsystems, namely financial accounting information system and management accounting information system [21]. The two sub accounting systems are different goals, the nature of the inputs and the types of processes used to convert inputs into outputs. Financial accounting information systems are intended for corporate external users, while management accounting information systems produce information intended for internal users, such as managers, executives and employees in decision making[22].

Management accounting information system provides management accounting information that can be used to improve productivity, efficiency and control which is an important factor for the achievement of competitive advantage [23].

\section{B. Management Accounting Information}

Information is a source of strength for an organization. Information can inform the organization of how the current operating performance is performing and help estimate and strategize on how to operate in the future. The ability to understand, digest, analyze and filter information is the key to growth and success for any professional in any industry. Information is available throughout the organization. Sales, marketing, human resources and managers need information to run their departments and make everyday decisions [24].

Uses the term "information" as data that has been transformed into meaningful and useful forms for users who need it. Information is data that has been converted into a form that has meaning and useful. In line with the statement argues that information is data that has been processed into something more meaningful[25].

Management accounting information is information that produced by a management accounting information system intended for strategic decision making [26]. Similar to the previous statement management accounting information can be defined as accounting information use is intended for the company's management in determining the strategic policy for competitive advantage[27].

Management accounting information refers to Accounting information that contains financial information generated from the flow of financial resources in the organization, production information generated from the physical flow of resources in the organization, employee information generated from the flow of people in the organization, and marketing information resulting from interaction with the market for products organizational products with the aim to be used by company managers in determining strategic policies[28]. Management accounting information is financial and non-financial information that results from the entire processing cycle of a company's business transactions used by managers for the company's competitive advantage

There are several criteria that can be used to measure the quality of accounting information, measure the quality of accounting information from the point of view of content dimension, form dimension and time characteristic dimension.

\section{Business Strategy}

Business strategies as plans, alternative options or solutions and decisions used to guide a company in generating greater profits and achieving a company's success. Business strategy is the basis for determining longterm goals and objectives of the company, the implementation of concrete actions and the sharing of resources needed in implementing the various objectives to be achieved company[29-30]. Business Strategy is a competitive and cooperative strategies that emphasize improvement of the competitive position of a corporation's product and service in a specific Industry or market segment[31]. Based on various definitions it can be stated that business strategy is a tactic or ways used by company managers to be a winner in business competition which consists of various activities that are integrated and well planned.

Business strategy that refers to the concept of competitive strategy: Cost leadership, differentiation, and focus [32]. Then the concept was adopted by some other experts such as states that business strategies measured through cost 
leadership, product differentiation and focus on market focus can influence information systems to produce competitive advantage[33].

\section{Conceptual Framework}

There are three main factors that affect the effectiveness of Accounting Information Systems consisting of: Information technology, business strategy and organizational culture [34]. The effectiveness of accounting information systems are influenced by business strategy which is the latest major approach in managing information systems[35]. In the modern system / present there is a growing interdependence between the company's information systems with business strategy and business capabilities of the company[36]. Business strategy is the pattern of the most widespread diffuse decision-making resources allocation and other more specific decisions, which affect the information system and information technology[37].

Previous research has generated empirical evidence that supports the concept of the influence of business strategy on the effectiveness of accounting information systems. Business strategy has significant effect on accounting information system[38-41]. Furthermore, the influence of business strategy on accounting information system is also evident hows empirical evidence that business strategy influential Significant to the effectiveness of accounting information systems[42-44].

Provide empirical evidence that business strategy significantly influence the performance of Accounting Information Systems. Based on theories and empirical evidence obtained from previous research that has been done by the researchers can be said that business strategy affect the accounting information system[45].

\section{DATA AND METHODOLOGY}

Respondents in this study were the sales manager, accounting manager and management accounting manager with a total of 162 respondents. Research data will be analyzed using and verificative analysis. Descriptive analysis used to describe the variables studied and obtain operational advice. The verificative analysis aims to test the research hypothesis that has been formulated previously. The proper analytical tool for performing verification is Covariance Based-Structural Equation Modeling or known as CB-SEM using Lisrell 8.50 software tool. The use of Structural Equation Modeling (SEM) allows researchers to unite some unobserved variables indirectly measured by the indicator and can be used to calculate measurement errors on observed variables[46].

The minimum sample size in order to perform data analysis using Covarian Based-Structural Equation Model (CB-SEM). Based on the rule of tumb the minimum sample size in this study is 85 units of management accounting on SOE's Indonesia obtained from 5 times the number of parameters (t) studied. The formulation of the research hypothesis is the third step in the study. hypothesis is a logically suspected relationship between two or more variables in the formulation of propositions that can be tested empirically. Then, formulation of the hypothesis is as follows:

TABLE I. HYPOTHESIS 1

\begin{tabular}{|l|l|}
\hline $\mathrm{H}_{0}: \gamma_{11} \leq 0$ & $\begin{array}{l}\text { Improved Business Strategy has no } \\
\text { effect on Improving the effectiveness of } \\
\text { management accounting information } \\
\text { system }\end{array}$ \\
\hline $\mathrm{H}_{1}: \gamma_{11}>0$ & $\begin{array}{l}\text { Improved Business Strategy Influence } \\
\text { on Improving effectiveness of } \\
\text { management accounting information } \\
\text { system }\end{array}$ \\
\hline
\end{tabular}

TABLE II. HYPOTHESIS 2

\begin{tabular}{|l|l|}
\hline $\mathrm{H}_{0}: \beta_{21} \leq 0$ & $\begin{array}{l}\text { Improved Effectiveness of management } \\
\text { accounting information system has no } \\
\text { effect on Improving the quality of } \\
\text { management accounting information }\end{array}$ \\
\hline $\mathrm{H}_{1}: \beta_{21}>0$ & $\begin{array}{l}\text { Improvement The effectiveness of } \\
\text { management accounting information } \\
\text { system has an effect on to Improving the } \\
\text { quality of management accounting } \\
\text { information. }\end{array}$ \\
\hline
\end{tabular}

TABLE III. HYPOTHESIS 3

\begin{tabular}{|l|l|}
\hline $\mathrm{H}_{0}: \gamma_{11} \beta_{21} \leq 0$ & $\begin{array}{l}\text { Enhancement Business strategy } \\
\text { through Effectiveness of management } \\
\text { accounting information system has no } \\
\text { effect on improving the quality of } \\
\text { management accounting information }\end{array}$ \\
\hline $\mathrm{H}_{1}: \gamma_{11} \beta_{21}>0$ & $\begin{array}{l}\text { Improved Business Strategy through } \\
\text { Effectiveness of management } \\
\text { accounting information system has an } \\
\text { effect on to improve management } \\
\text { accounting information quality }\end{array}$ \\
\hline
\end{tabular}

\section{RESULT}

The evaluation of structural model is aimed to know the influence of Business Strategy (X1 on the effectiveness of management accounting information system (Y) and its implication on quality of management accounting information ( $\mathrm{Z})$. Result of data processing and modeling using LISREL software as follows : 
TABLE IV. STRUCTURAL MODEL PARAMETERS

\begin{tabular}{|c|c|c|r|r|r|r|r|r|}
\hline $\begin{array}{c}\text { Dependen } \\
\text { variabel }\end{array}$ & Mediator & $\begin{array}{c}\text { Independen } \\
\text { variabel }\end{array}$ & $\begin{array}{c}\text { estimated } \\
\text { Default }\end{array}$ & estimate & \multicolumn{1}{c|}{ error } & $\begin{array}{c}\text { Z- } \\
\text { value }\end{array}$ & P-value & R2 \\
\hline EMAIS & & BS & 0,290 & 0,046 & 0,149 & 0,306 & 0,460 & 0,4571 \\
\hline QMAI & & EMAIS & 0,676 & 0,571 & 0,075 & 7,618 & 0,000 & 0,2088 \\
\hline QMAI & EMAIS & BS & 0,190 & 0,026 & 0,085 & 0,306 & 0,420 & $-0,019$ \\
\hline
\end{tabular}

Source : Output Calculation of Lisrel 8

Based on the information obtained from table 4.5 , the interpretation of the evaluation results of the structural equation model can be explained as follows:

1. The magnitude of the influence of business strategy variables on the effectiveness of MAIS is -0.029 can be interpreted every increase of business strategy 1 unit resulted in decreasing the effectiveness of management accounting information system of 0.029 with the assumption that other variables do not change.

2. The effectiveness of MAIS on the quality of management accounting information is equal to 0.676 , meaning that each increase in the effectiveness of management accounting information system 1 unit, the quality of management accounting information increased by 0.676 assuming other variables do not change.

After all models tested and obtained model fit with the data then the next stage is to test hypothesis, as follows:

Hypothesis 1: The Influence of Business Strategy to Effectiveness of management accounting information system. Business Stretegi hypothesized to have an influence on the effectiveness of management accounting information systems. To test the allegations of the study, the test hypothesis was statistically expressed in section III. Base on result, we known that p-value is 0.620 and greater than 0.05 then Ho is accepted. This means that improving the Business Strategy does not affect the improvement of management accounting information system effectiveness.

Hypothesis 2: The Influence of effectiveness management accounting information system on Quality management accounting information.

Effectiveness of management accounting information system hypothesized affect the quality of management accounting information. To test the allegations of the study, the test hypothesis was statistically expressed in section III. Base on the result know that, p-value of 0.000 is smaller than 0.05 then Ho is rejected, it means the increased effectiveness of management accounting information system has an effect on the quality of information management accounting.

Hypothesis 3: The Influence of Business Strategy through Effectiveness of management accounting information system affect the quality of management accounting information.

Business Strategy through the effectiveness of management accounting information system hypothesized affect the quality of management accounting information. To test the allegations of the study, the test hypothesis was statistically expressed at section III. Base on the result known, p-value of 0.620 is greater than 0.05 then Ho accepted, meaning that the improvement of business strategy through the effectiveness of management accounting information system has no effect on the increase.

\section{DISCUSSION}

The result of hypothesis testing shows that the P-value is greater than 0,05 so that it can be concluded that the improvement of business strategy does not affect the effectiveness of management accounting information system at the level of significance $(p)=0,660>0,05$. The result of hypothesis testing shows that the effectiveness of management accounting information system is not influenced by the changes that occur in the company's business strategy.

Furthermore, it is known that the influence of business strategy on the effectiveness of management accounting information system in SOE companies in Indonesia is -0.029 , it can be interpreted that the improvement of 1 unit of business strategy causes the change of management accounting information system effectiveness of -0.029 . The negative results show the proposed hypothesis can not be confirmed by the empirical data collected. Business strategy has no effect on the effectiveness of accounting information system is explained by some of the following conditions:

1. The business strategy applied is not accommodated in the applications available within the company. This condition is evidenced melallui responses of respondents who generally stated Application Management Accounting Information Systems available today never provide features / menus that accommodate cost leadership strategies, product / service differentiation and Focus,

2. There are many SOE companies that use the application by buying the finished software package. The result of descriptive analysis on software procurement proves that $49.4 \%$ of state-owned enterprises in Indonesia are currently using infromation system applications procured through the purchase of ready-made application software packages, this is the cause of infromation system applications used in SOE companies currently not relevant to the needs of various users.

3. Based on the results of interviews with respondents, there are some companies have not used the application of accounting information systems in processing financial and non-financial data and there are some state-owned companies are still in the development / design, so can not be assessed optimally by the respondents

It can be said that the results of this study have not been fully able to prove the opinion put forward by [36] that the effectiveness of accounting information systems is influenced by business strategy which is the latest major approach in managing information systems. in today's 
modern system there is a growing interdependence between accounting information systems (finance and management) of firms with business strategies and business processes[28], and opinions expressed by [31] that business strategies used by organizations provide support for management accounting information systems in providing information from the internal and external environment of the organization to managers in need.

The results of this study can not be said to fully confirm the use of innovation in business strategy affect the implementation of management accounting information system[47]. Then [40] conducted research on 62 managers in Australia, the results showed that business strategies and perceptions of environmental uncertainty are important antecedents that influence in effective management accounting information systems. Next research results [41] proves that business strategy has a significant effect on Accounting information system. research conducted by David [44] The study was conducted on 112 CEOs in 218 hospitals in Spain, the results of the study prove that the satisfaction of management accounting information system used is influenced by the business strategy used by the company. Similarly, the results of research conducted by [45] proves that business strategy through stratgic alignment influences the success of management accounting information system in companies in China.

The results of this study have confirmed previous studies that have succeeded in proving the effect of the effectiveness of management accounting information systems which are characterized by optimal use of the system and user satisfaction on the quality of management accounting information [48-52].

The results of this study have proven the theory that has been stated by experts, a quality management accounting information system will produce quality management accounting information[26]. The effectiveness of management accounting information systems describes an information system that provides management accounting information needed to meet certain management objectives[22].

\section{CONCLUSION}

Based on testing the hypothesis, this study has successfully confirmed the research objectives stated earlier, that the effectiveness of management accounting information systems has been empirically proven to influence the quality of management accounting information, while the influence of business strategies on the effectiveness of management accounting information systems and the influence of business strategy through effectiveness of management accounting information systems affect the quality of management accounting information, not yet confirmed in this study. Furthermore, the results of hypothesis testing provide empirical evidence that: there is no indirect effect of business strategy onthe quality of management accounting information through the effectiveness of management accounting information systems. This means that: because the business strategy does not affect to the effectiveness of management accounting information systems, the business strategy does not have an indirect influence on the quality of management accounting information on the management accounting unit of SOE's in Indonesia. This research has successfully demonstrated an interaction between "improving business strategy through the management of accounting information systems" and "improving the quality of management accounting information" in SOEs in Indonesia. Thus it can be concluded to improve the quality of management accounting information, company managers must be able to improve the effectiveness of management accounting information systems. The effectiveness of management accounting information systems can be improved if the implementation of business strategies also increases.

\section{REFERENCES}

[1] Mc. Leod, R \& Schell, G. P, "Management Information System," 10th ed., New Jersey: Pearson Education, 2007.

[2] Laudon, Kenneth. C and Jane P. Laudon, "Management Information System: Managing The Digital Firm," 12th ed, New Jersey: Pearson Education Inc, 2016.

[3] Lupasc, Adrian Lupasc, Iona Zamir and Christina Gabriela," New Valences For The Financial Accounting System," The Annals of "Dunarea de Jos" University of Galati Fascicle I. Economics and Applied Informatics. Years XV . ISSN 1584-0409, 2009.

[4] Bodnar, George. H and William S. Hoopwood, "Accounting Information Systems,” USA: Pearson Education Limited,2014.

[5] Azhar Susanto. "Sistem Informasi Manajemen (Pendekatan Terstruktur - Risiko Pengembangan)," Bandung: Lingga Jaya, 2013.

[6] Sacer, Ivana Mamic; Katarina Zager, Boris Tusek, “Accounting Information System's Quality as The Ground for Quality Business Reporting," IADIS International Conference e-Commerce,2006

[7] Wang, R. Y. \& Strong, D.M. Beyond accuracy: What data quality means to data consumers. Journal of Management Information Systems, Vol. 12, No. 4, pp. 5-33,1996.

[8] Gelinas U, A. Oram \& W. Wriggins, "Accounting Information Systems”. Boston: Pwskent Publishing Company,1990.

[9] De.Lone, William H and Ephraim R. McLean, "Information System Success: The Quest for The Dependent Variable. Information System Research. 3 (1) (March),1992, Pp.60-94.,1992.

[10] Deghanzade, Hamed; M.Ali Moradi \& Mahvasan Ragibhi,"A Survey Of Human Factors Impact on The effectiveness of AIS", International Journal Of Bussiness Administration. Vol 2. No.4, 2011.

[11] Post, G. V \& Anderson, D. L, "Management Information Systems Solving Business Problems with Information Technology," 3rd ed. Singapore: McGraw-Hill, 2003.

[12] Nicolau, A.I, "A Contigency Model Perceived Effectiveness in Accounting Information Systems: Organizational condition and controll Effect," International Jurnal Of Accounting Information System. 1(2), 2000.

[13] De.Lone, William $\mathrm{H}$ and Ephraim R. McLean. "Information Systems Success: TheQuest for the Dependent Variable". Information System Research The Institute of Mangement,2003.

[14] Kearns, G.S \& A.L. Lederer, "The Effect of Strategic Alignment on the Use of IS-based resources for competitive advantage," Journal Of Strategic Information Systems. Vol.9. page 265-293, 2000 .

[15] Issa-Salwe,munir ahmed,khalid aloufi and muhammad kabir, "Strategic Information Systems Alignment: Alignment of IS/IT with Business Strategy," Journal of Information Processing Systems, Vol.6, No.1.pp 121-128, 2010. 
[16] Romney, Marshall B \& Steinbart, Paul John, "Accounting Information Systems,” 12th ed., USA: Pearson Education, 2012.

[17] Azhar Susanto and Meiryani, "The Quality of Accounting Information System and its Impact on the Quality of Accounting Information: User Ability and Top Management Support”. Journal of Engineering and Applied Sciences, 13: 384-387, 2018.

[18] Zahirul Hoque, Strategic, "Management Accounting: Concept, Processes and Issues. Second Edition," USA: Spiro Press, 2004.

[19] Considine,Parkes, Olesen,Speer and lee, "Accounting Information System:Understanding Business Process". Australia: Jhon Wiley \& Sons, Ltd, 3rd ed, 2010.

[20] Puspitawati, Lilis., "The Analysis of Effectiveness Measurement In Accounting Information Systems Through Competence Factor Of Information System User-Research on Higher Education in Bandung”, IJABER, Vol. 14, No.2., pp.815-841. Serials Publications, 2016.

[21] Boockholdt, J. L. "Acounting Information System," Singapore: Mc. GrawHill, 5th ed,1999.

[22] Hansen, D.R; Mowen, M.M \& Liming Guan., "Cost Management Accounting \& Contro"l. USA: South-Western Cengage Learning,6th ed, 2009.

[23] Azhar Susanto., "The Empirical Testing How the Quality of Accounting Information Systems Affected by Organizational Structure Research Atuniversities in Bandung". Asian Journal of Information Technology, 15: 1098-1105, 2016.

[24] Baltzan, Paige. "Business Driven Technology". 6th Ed. USA: Mc.Graw-Hill International, 2015.

[25] Marakas, George M \& James A. O'Brien. "Introduction to information System". Boston: McGraw-Hill.Inc,6th ed, 2004.

[26] Heidmann, Marcus. "The role Management Accounting System in Strategic Sensemaking”. Germany: Deutcher Universitats Verlag,2008.

[27] Zahirul Hoque. "Strategic Management" Accounting: Concept, Processes and Issues,” 2nd Ed. USA: Spiro Press, 2004.

[28] Belkaoui, A. R. "Behavioral Management Accounting." London: Quorum Books, 2002.

[29] Kourdi, Jeremy. "Business Strategy: A Guide to Taking Your Business Forward," 2nd Ed. London: Profile Books Ltd. 2009.

[30] Campbell, D Edgar and G Stone House, "Business Strategy: An introduction. Second Edition". United Kingdom: ButterworthHeinemann an Imprint of Elsevier Sciencez, 2002

[31] Wheelen Thomas L, David Hunger, Alan N. Hoffman and Charles E Bamford,"Strategic Management and Business" Policy: Globalization, Inovation and Sustainability. USA: Fourthteenth Edition, 2015.

[32] Porter, Michale. E, "Competitive Advantage: Creating and Sustaining Superior Performance," New York: The Free Press, 1985

[33] Haag, Sthepen \& Maeve cummings, "Management Information System for Information age". 9th ed., New York: Mc.Graw-Hill, 2013.

[34] Romney, Marshall B \& Steinbart, Paul John. "Accounting Information Systems,” 13th ed., USA: Pearson Education, 2015.

[35] Ward, Jhon \& Joe Peppard,"Strategic Planning for Information Systems," 2nd ed., England: Jhon Willey\& Sons, 2002.

[36] Susanto, Azhar, "Second Order Model for Measuring the Impact on Information Technology on the Quality of Accounting Information Systems," Journal of Engineering and Applied Sciences 12 (4).1018-1027. Medwell Journal,2017.

[37] Gottschalk, Petter. "E- Business Strategy: Sourcing and Governance," USA: Idea Group Publishing, 2006.
[38] Jenster, Per V, "Firm Performance and Monitoring of Critical Success Factors in Different Strategic Contexts," Journal Of Management Information System. Vol.3., Issue 3,1986.

[39] Volonino, Linda A \& Hugh J. Waston.. "The Strategic Business Objectives Method for Guiding Executive Information Systems Development," Journal of Management Information Systems. Vol. 7(3):27-40 , 1991.

[40] Chong, V.K. and Chong, K.M. "Strategic choices, Environmental uncertainty and SBU performance: a note on the intervening role of management accounting systems," Accounting and Business Research. Vol. 27, pp. 268-276,1997.

[41] Gilbert, Arthur H and Joseph F Singger, "An Analysis of The Relationship among perceived environmental uncertainty and Business strategy," Proceedings of the Academy of Information and Management Science. Vol 2, No.2, Myrtle Beach, 1998.

[42] Jhonson, Alice M, "An analysis of the relationship among perceived environmerntal uncertainty and Business Strategy," Proceedings of the Academy Of Information and Management Science. volume 2 Number 1 Myrtle Beach, 1998,2001.

[43] Md. Zabid Abdul Rashid, Saadiatul Ibrahim \& Samsinar Md Siddin.,"The Relationship Between Strategic Information Systems and Business Strategies in Malaya," Jurnal Pengurusan. No. 22. Page 67-89, 2003.

[44] Gill, David Narajo," The Role of Sophisticated Accounting System in Strategy Management," The International Journal of Digital Accounting Research. Vol. 4, N. 8, pp. 125-144, 2004.

[45] Xiaoying, Dong; Liu Qianqian \& Yin Dezhi, "Business Performance, Business Strategy and Information System: Strategic Aligment: And empirical Study on Chinese Firm.,'Tsinghua Science And Technology. Vol 13. Number 3. June 2008

[46] Hair, Joseph F.,G. Thomas M. Hult.,Christian M. Ringle, Marko Sarstedt, "A Primer on Partial Least Squares Structural Equation Modeling (PLS-SEM),” USA: Sage Publications, inc, 2014.

[47] Ghasemi, et.al. "The Relationship among Strategy, Competition and Management Accounting Systems on Organizational Performance," European Online Journal of Natural and Social Sciences. Vol.4, No.3 pp. 565-581, 2015

[48] Susanto, Azhar, “The Influence to Accounting Information Quality and Its Implication to the Good Study Program Governance. International Business Management. 10 (24). page 5767-5776, 2016.

[49] Susanto, Azhar. "How the Quality of Accounting Information Systems Impact on Accounting Information Quality (Research on Higher Education in Bandung)," Journal of Engineering and Applied Sciences 12 (14) 3672-3677. Medwell Journal, 2017.

[51] Gul, F.A and Chia,Y. Ming. "The Effects of Management Accounting Systems," Perceived Environmental Uncertainty and Decentralization on Managerial Performance: a Test of Three Way Interaction. Accounting, Organization and Society. Vol, 19. No. 4/5, pp: 413-426. Elsevier Science Ltd, 1994.

[52] Rani, D. L. \& Kidane, F. 2012. Characteristics and Important Quality Factors of Management Accounting Information System. Radix International Journal of Banking, Finance and Accounting (RIJBFA).Volume 1, Issue 7, ISSN:2277-100X, July, 2012. 